\title{
Giorgia Grandi
}

\section{Narrating the Ascetic Model, Its Context and Its Hero(in)es: A New Proposal for Jerome's Letters and Lives}

\section{Pripovedovanje asketskega vzora, njegov kontekst in junaki/junakinje: nov predlog za Hieronimova Pisma in Življenja}

Abstract: Epistles 1-17, 22-23, 41-43, 68, 70, 72, 107, 130, despite being different from one another in length, addressee, and content, can be considered narrative letters show specific narrative techniques and strategies. What makes them ,narrative' is the author's behaviour: he is pleased to narrate episodes, places, memoirs, novels, or exempla to his friends, trying to persuade them to embrace (or persist in following) his monastic way of life. We can talk about, weak narrativity' because they incorporate a proliferation of ,minor' narrative genres to be compared to the Lives and divided into three main periods. The inner and extratextual functions of these epistles change throughout these periods, especially since letter-writing is: "a form not only of representing but of constituting reality«, of constituting, in the case of Jerome, his reliability and the monastic movement itself, its history, its heroes and heroines.

Keywords: Narrativity, Epistles, monasticism, fiction, novel, Lives of Paul, Malchus and Hilarion

Povz̧etek: Čeprav se Pisma 1-17, 22-23, 41-43, 68, 70, 72, 107 in 130 med seboj razlikujejo po dolžini, po naslovniku in po vsebini, jih lahko razumemo kot narativna pisma, saj izkazujejo posebne narativne tehnike in strategije. ,Narativne' jih napravlja avtorjev odnos: všeč mu je opisovanje dogodkov, krajev, spominov, romanov ali exempla, s tem pa želi svoje prijatelje prepričati, da bi sprejeli ali nadaljevali življenje po njegovem meniškem idealu. V Pismih lahko govorimo o "šibki narativnosti ", ker uporablja manjše narativne žanre, in jih zato lahko primerjamo z Življenjepisi ter jih razdelimo v tri glavna obdobja. Znotraj- in zunajbesedilne funkcije teh pisem se skozi obdobja spreminjajo, predvsem zato, ker je pisanje pisem »oblika, ki ne le prikazuje, marveč vzpostavlja resničnost«. Pri 
Hieronimu vzpostavlja njegovo lastno zanesljivost in meniško gibanje nasploh, skupaj z njegovo zgodovino ter z junaki in junakinjami.

Ključne besede: narativnost, Pisma, meništvo, fikcija, roman, Življenja Pavla, Malha in Hilariona

Having studied the excellent works of Cain (2009), Canellis (2002), and Stoico (1972) about the Epistolary of Saint Jerome, in my doctoral dissertation (Grandi 2014b), I suggested an alternative classification for his letters, following my criteria which are based mainly on a linguistic, narratological, stylistic and rhetoric analysis. I concluded that we could find six macro-categories: paraenetic, eulogistic/consolatory, functional, polemic, exegetical, and narrative letters. This last category results from my consideration of the content and structure more than of the addressees. ${ }^{1}$ I aimed to reveal and study their intimate kinship with the Lives (Hilarion, Malchus, Paul) written by the author more or less in the same period. ${ }^{2}$ All these masterpieces were the product of Jerome's fictional vein, need for communication, and attitude towards storytelling ${ }^{3}$ exploited to support the rapidly expanding monastic movement. I accordingly argued that his letters 1-17, 22-23, $41-43,68,70,72,107,130$, despite being different from one another in length, addressee, and content, showed specific narrative techniques and strategies ${ }^{4}$. What makes them , narrative letters' is the strategy of the author: ${ }^{5}$ he is pleased to narrate episodes, places (in primis desert and sea), memoirs, novels, or exem$p / a^{6}$ to his friends, trying to persuade them to embrace (or persist in following) his ideal monastic way of life. In doing this, he is always attractive and entertaining, thanks to peculiar narratological tools. For Letters, in particular, we can talk about ,weak narrativity' because they »incorporate a proliferation of ,minor' narrative genres: anecdotes, gossips, and hearsays, jokes, dream narratives, eckphrasis of paintings " (McHale 2001) that we are going to analyze in this paper.

Nevertheless, the intra- and extratextual functions of these epistles change throughout time, especially since letter-writing is: "a form not only of representing but of constituting reality« (Bruner 1991), of constituting, in the case of Jerome,

1 Both Canellis (2002) and Cain (2009) tend to approach this type of letters - at least a part of them - as amicales or ad familiares. Also see Gibson 2012 and Malherbe 1977.

2 Following Cavallera's chronology (1922), Jerome started his career as an epistolographer in 374 with narrative letters and wrote the most considerable part of them between 374 and 385 . While the chronology of Lives is still discussed, they were probably written between 376 and 390.

3 Palmer proposes: "Theorists from various disciplines have suggested that life plans are scripted on fairy-tales' patterns and in a sense we are all novelists. " $(2004,186)$ We can consider that this is particularly true for our saint.

4 Here I have to thank the organizers of „Epistula narrans. Narrative modeling in Latin epistolography. International graduate and early career conference" (Tübingen, July 5-7, 2018) conference; the present paper shows the results of a research began on that occasion.

5 We can talk about »narratives that are incorporated in non-narrative genres« by Jerome (De Jong 2014, 17).

6 Hagendahl highlights that Jerome tries to impress the reader with these witty remarks and commonplaces $(1958,104)$. 
his reliability and the monastic movement itself, its history, its heroes and heroines. So, following Cavallera's chronology, I have identified three main periods in Jerome's narrative production. ${ }^{7}$ In the desert (374-376), Jerome complains about his loneliness and lets the readers meet him as a hermit through letters that are at the same time factual and fictional and through Vita Pauli, the first step in shaping a new history of monasticism. In Rome (384-385), he primarily addresses long, paraenetic letters about the lives of holy women to Marcella, building his influence and authoritativeness in the Western world and promoting himself against other competing groups. At the end of this period, looking back to his Roman experience, he also writes Vita Malchi, turning his relationship with Paula into a breath-taking novel of chastity. More or less in the same period, looking forward to Bethlehem and beyond, he narrates the adventures of saint Hilarion, enriching them with historical hints and revealing that the late antique world was changing and challenging new gauntlets. In Bethlehem, until his death, he also writes something that we can almost call ,metaliterature', explaining why he frequently uses controversial issues in these works.

Before analyzing the internal narrativity of Jerome's Letters and Lives, we first need to remember that, as the writing of letters in antiquity was strictly standardized (Cugusi 1983; Fowler 1982), Jerome was not going to break the rules which he had studied and admired. At the same time, he was well aware that, to spread the new Christian message at its best, it was necessary to employ and regenerate classical tools, to use epistles - as Antin would say - as a ,passe-partout' genre (Antin 1951, 123). As I have elsewhere said (Grandi 2010), the Lives also can be considered (Fuhrmann 1976, 87) as Formexperimenten, not belonging to a definite genre. The blurring lines of all these texts reflect Jerome's complex personality and define the holy woman/Christian heroine (Letters) and those of the holy man/ Christian hero (Lives) in second place Jerome as an auctoritas. ${ }^{8}$

Ep. 1 to Innocence is very interesting for us. ${ }^{9}$ It can be entitled History of a martyrdom's (epic) fail, and it is a sort of ideal entanglement between Epistles and Lives; actually, I would dare to say that, having been written in $374,{ }^{10}$ a few years before Vita Pauli, it is the matrix for both of the collections. It derives its form from Acta martyrum, ${ }^{11}$ a well-known and structured genre in ancient Christianity, expiring after the end of persecutions (Van Uytfanghe 2001). It is the report

The context is particularly important since joining events with their times produces an easier comprehension of the one from the other and a better comprehension of the whole continuative history of the author.

8 To do so, Jerome adapts himself and his style to his audience (Vessey 1993): for example, he often literary turns himself into a woman (even into the sinful Magdalene) or in other characters as Lazarus, trying to convince his addressees to act in a monastic (or eremitic) manner.

9 For the literary analysis of this epistle, see Praet et al. 2014, 385, in which the text is defined as a, hybrid composition' and in which the authors find a connection with hellenistic novel, in particular with Eliodorus' Aethiopica.

10 The chronology is not clear: Grützmacher $(1969)$ and Cavallera $(1922,53)$ propose a late dating $384 / 385$-, while Hagendahl $(1958,100)$ dates it a decade earlier.

11 For example from Acts of Paul and Thecla (e.g. the ,Thecla motif' of gender-shift). 
of a miracle, which occurred at the time of Diocletian in Vercelli: the story of a woman who, wounded seven times by her persecutors and tortured to death, does not even faint, but rather lives to testify to the greatness of God. This is the supernatural story of a martyr ${ }^{12}$ - and a monk is exactly a martyr in pectore, we can say a ,failed' martyr (because of the end of persecutions), or a new type of it (for he loses his life in a metaphorical, not in an authentic way). Because of this, for Jerome, the unnamed woman stands for the prototype of monks and nuns. For these reasons, we can ascertain that the text, although addressed (which is a sine qua non condition for letters) to Innocence, has less of the genre of the letter and more of the hagiography. In particular, it has many features in common with Vita Malchi, and its Lust am fabulieren: literary quotations (the initial nautical metaphor, the rubigo, the unnamed female heroine), narrative mechanism (such as the claimed suicide/Scheintod, bloody details, and witty trick to gain freedom...), ${ }^{13}$ and a stylistic pattern that resembles that of a novel (an antagonist, the intervention of the marvellous and desirable happy-ending). All of these entertain the reader. Nevertheless, the latter tends to praise Evagrius, a good friend of Jerome who intervened in the persecution and prevented the woman's second death. This brings the reader back to reality, giving him the sensation that God is operating in history through the group to which Jerome belongs. ${ }^{14}$

Ep. 2 to Theodosius and other hermits is a very brief letter in which Jerome praises the desert. Two motifs are substantial: the drawing of the solitudo as a locus amoenus, and the captatio benevolentiae towards the abbot of the desert. Jerome here introduces himself as a sinful man needing forgiveness, using two central metaphors that will often return in his production: the one of the good shepherd and that of the prodigal son; they are a sort of professio humilitatis that icastically resumes the saint's biography and his experience in a desert scene as the very place of monasticism. The Christian themes intersect classical literature, and Jerome also uses a metaphor derived from Virgil: the ship that has a tormented journey (=life) but still arrives safely at the harbour. All these literary expedients end in a sort of prayer or autoreferential propitious motto for a long journey, partially assuming the function of a propemptikon ${ }^{15}$ full of pictures and sketches about Jerome's everyday life that evoke narrative forms of coherence, without fully submitting to them (McHale 2001, 162): he is narrating by himself about himself.

Closer to the attitude of the first letter and of the Lives is Ep. 3 to Rufinus. In this letter, Jerome compares himself to Bonosus, whose life is an incredible journey among the rocks of ascetic life (again, the nautical metaphor) to gain his place on

12 In effect, as Praet et al. 2014, 408, say: it is not a martyr but a secular trial on adultery, a case of Unterhaltungsliteratur as Kech (1977) calls it.

13 For other particulars, see Capponi 1989.

14 In effect, Evagrius was a pro-Nicene activist who had translated Athanasius's Vita Antonii, dedicating it to Innocence alike, so Jerome with this letter wanted to follow in his footsteps (Praet et al. 2014, 388) or at least to give a first essay of a similar operation.

15 The definition of ,lettere augurali' (greetings letters) is by Paolo Cugusi $(1989,396)$. 
an island surrounded by cliffs wildlands and seas. On the contrary, a 'storm' blows Jerome from Aquileia. We can consider this letter, written in 375, the first example of male hagiography (of Bonosus, seen as a puer-senex) by the Saint of Stridon. However, it is also an account of Jerome's journey throughout the Mediterranean $\mathrm{Sea}^{16}$ and collects many details that will re-appear in the Lives (the language of militia Christi, the attitude of the two main characters, the references to John of Patmos and Vergil). In Ep. 4, to Florentinus, Jerome again praises his friend Rufinus and identifies himself with Lazarus (»Hieronyme, veni foras"), showing his preference for complicated, extreme, borderline figures. Closely connected to these last letters and their narrative construction of friendship and solitude are $E p .7-13,{ }^{17}$ in particular, Ep. 7 to Chromace, Eusebius and Jovinus, where Bonosus is named filius ikthus and where desert and sea are one more time compared, precisely as the sinful life of Jerome ${ }^{18}$ and the perfect life-style ${ }^{19}$ of his friend.$^{20}$ It seems that this holy paradigm is not sufficient to promote an ideal way of life: Jerome has read Evagrius' translation of Vita Antonii and needs his archetype, especially to convince Heliodorus after the failure of his invitation in Ep. 14; he needs to write V. Pauli.

In Ep. 5, the first explicit references to V. Pauli and the upcoming V. Malchi appear. ${ }^{21}$ Here it starts to become apparent that all these fictional characters are Jerome's alter egos (and, vice-versa, Jerome introduces himself as one of them) because many details that here are referred to him return in Lives to characterize their heroes (above all the contrast between loneliness and relationships in the desert). In this epistle, he also reveals his tireless desire for reading and writing. Ep. 6 is a quarrel that adopts the question-answer strategy of Acta martyrum and uses juridical language. What is most interesting about this is the question asked by Jerome if his native land still exists. Let us think that he is relatively isolated in the desert near Chalcis (every day, he meets messengers, travellers and mail carriers) (Clausi 2013, 135). His loneliness appears to be predominantly a topos, mourning for being distant from the hot spots of Rome to the extent that the very same question appears in a very similar context in V. Pauli (where we find Paul isolated in the middle of a harsh desert, curios about the world left behind

16 As in Ep. 46 and Ep. 108 or in Vita Hilarionis. Hagendahl $(1958,100)$ proposes that the historical journey across the sea impressed Jerome so much that it induced him to talk frequently about this experience in his texts.

17 Here he proves to be a loyal friend through the report of some episodes, underlining again his solitude. Ep. 9 shows many references to classical narrative literature (e.g. Verg., Aen. 4.366f.; Hor., Carm. 2.13.39f. e 1.23); Ep. 11-13 display a synkrisis of passages about forgiveness (a technique that Jerome frequently uses for his exegesis); lastly, Ep. 8, among the other narrative motifs, presents a brief historical excursus about the people called, Caschi'.

18 Jerome here claims, as in Ep. 4, to be dead and waiting to be brought back as Lazarus.

19 "Si vis perfectus esse" is the theme of parenetic epistles, that is strictly connected with the ideal life of the characters presented here, in narrative letters and Lives (Grandi 2014).

20 Another detail that lends a narrative allure to the letter is the metaphor used by Jerome to describe his joy: even superior to that of the Romans after their victory at Cannae.

21 For example, the first lines of the letter quote (or are quoted?). The chronology of the epistle is uncertain, between 375 and 377, whereas V. Pauli dates tp 376. See Hier., V. Pauli 6.2. 
but not longing for it) ${ }^{22}$, linking the two biographies definitively. In addition, in this letter, Jerome starts to complain about ,false monks with long hair', which also appear in V. Pauli and Ep. 22. Ep. 10 technically is not a narrative letter, but a text explaining the relationship between the Epistolary and the Lives: they are strictly interrelated; they complete each other for themes, suggestions, and Jerome's reflections. Here he dedicates his $V$. Pauli and claims to have adopted a simple style to be read by everyone; actually, we know that he writes with chosen words, classical echoes, many samples of universal history drawn from the Bible colourful descriptions. ${ }^{23}$ In Ep. 10, he speaks about ,eastern merchandise' and works that are already condita, maybe referring to a germ form of the upcoming last Lives. A few evangelical metaphors, depicting the contrast between East and West, the story about the monks of the desert spoiling its solitary life, ${ }^{24}$ and the sea element again, are instead the content of Ep. 15-16 to Damasus and prepare Jerome's coming to Rome, providing his professio fidei to the pope and his fashioning as an exegete. The end of Vita Pauli and the prologue of Vita Hilarionis echo these episodes. In the end, the topos of the rubigo linguae and the Virgilian sentence »hospitio prohibemur harenae ${ }^{25}$ in Ep. 17 leave no more doubts about the link between Lives and Letters. In these, Jerome uses polemic hints against false monks, and a desert suddenly becomes uninviting. In all these letters of the first period, he tells us all about his life in the desert and his feelings; it is a diary, but it is also fictional, ${ }^{26}$ rich in topoi, and intended for a vast public in Rome and beyond: it is the saint's novel.

The second period of his life and his narrative letters ${ }^{27}$ opens in 385 in Rome. In the desperate moment when he was the object of resentment and charges, he felt he had to return to the tale (probably a few years before V. Malchi): violent sketches of secular Roman life, counterposed to the first female hagiographic portraits, ${ }^{28}$ and the angulus theme here prevail, together with the narratological tool of flash-back. ${ }^{29}$ Lastly, the narrative epistles of the third period, when Jerome

22 Paul despises the cities and appreciates the desert, but this in only rhetoric: Jerome is well aware of the perils of a desert that is far from his ideal and, at the same time, of the possibilities offered by Rome.

23 Gerlinde Huber-Rebenich $(1999,207)$ supposes that Jerome sent V. Pauli to Paul because of his huge library: he could have the economic and technical means to spread the text, moreover Jerome asks in exchange for a book.

24 Depiction of contrasts that he renews in Ep. 17, where the monks become the real monsters of the desert, in opposition to the friendly creatures of V. Pauli: »Melius est inter feras habitare. « (Ep. 17.3; V. Pauli 72.8-9)

25 Verg., Aen. I, 539 that Jerome ,translates' in »non mihi conceditur unus angulus heremi« (Ep. 17.3; V. Pauli 72.9-10).

26 In claiming this, I am not assuming that Jerome is inventing his staying in the desert, but that he has the attitude of a good narrator, which he derives from Late antique and classic literature.

27 For the narrative characteristics in this period, I refer you to my recent paper presented in Rome at the conference Girolamo e Roma (Rome, 30 September - 3 October 2019): „Bethlehem contra Romam? ॥ tema dell'angulus declinato nelle Epistole geronimiane" to be published in the acts of the conference (see Grandi 2021).

28 For a general introduction to the topic, see Coon 1997.

29 See the dream narrative of Ep. 22 or of V. Hilar. in Nazzaro 2013. 
settles in Bethlehem, are merely occasional and include concise stories, such as that of Demetriades' choice, of Didymus the Blind (an excursus and a fanciful exemplum to support the reasoning of the letter), of the Beautiful Israelite Bride (metaphor of the saint's relationship with the classics), or that of the mother and daughter in danger of backsliding, ${ }^{30}$ to discredit Vigilantius. Eventually, around the end of the century, Jerome shifts towards meta-narration: he wants to explain why he is telling stories and working, mainly because he now has a broader audience in the eastern and western world. Through these letters, he becomes pervasive in the ancient world to the point that, finally, when he describes his journey through the desert and the Holy Land (Cain 2013), he does not want to transmit a memorial travel diary, but to let poor people from all over the known world make the same journey, with him, at least in a spiritual sense. Jerome auctor and agens are now closer than ever because he shows us his methods, working routine, and studiolo.

The same hazy line between fictional and factual events marks the Lives, too. I have elsewhere (Grandi 2017) discussed some of the Lives' sources, here I desire to restate the ambivalence of their provenience: history and novel, introducing some new considerations on their narrativity and registering new findings. ${ }^{31}$ First of all, if Paul and Anthony are primarily Christian and religious characters, Vita Pauli's marked dependence from (or, rather, opposition to) Evagrius/Athanasius' Vita Antonii, ${ }^{32}$ Malchus is a pagan novelistic hero, and Hilarion is a historical figure with exceptional traits. Puer-senex, theios aner, thaumaturge, and wrestler, Hilarion's biography shares features with neo-platonic philosophers, Christ in the Gospels, and Jerome himself, as we know, but also with Alexander the Great. ${ }^{33}$ For example, to Curtius Rufus's historical work, Jerome owes a linguistic pattern for natural descriptions (e.g., Curt., Hist. Al. 4.7.1-32; 7.10.1-2.) and an entire episode related to the death of the saint/emperor (10.5.1-37; Hier., V. Hilar. 44, 47.): a woman, whom he has helped, dies, overwhelmed by grief, right after her champion. ${ }^{34}$ To Great Alexander's novel (a famous novelistic biography) by Ps-Callisthenes (or maybe to its Latin translation from $3^{\text {rd }}-4^{\text {th }}$ century by lulius Valerius), $V$. Hilar. owes the strategies to resume the hero's life during the narration (cap. 35; Hier., $V$. Hilar. 9-13), the scene of the contention for his corpse (cap. 34; Hier., V. Hilar. 47), or even the chariot race (cap. 19; Hier., V. Hilar. 20). Last, to Plutarch, Life of Alexander, Hilarion's biography is indebted for some details: the prologue that diverts

30 Ep. 117 presents, for example, these formulas that betray a narrative allure: "rettulit mihi quidam« and »narrare surdis fabulam«.

31 But, like Hagendahl $(1958,94)$ says, it is beyond human individual resources to find out each source of Jerome.

32 Evagrius's translation with its novelty inspires Jerome, but at the same time the saint feels competitive with his source, so he replaces Antony with Paul (older and holier) and create , another' Antony (see Leclerc 1988).

33 A similar process has been studied for Vita Antonii by Cameron (2000) and Rubenson (2006).

34 Vita Malchi also shares a peculiarity with History of Alexander the Great, the particular of the goatskin used to cross the river (Curt., Hist. Al. 7.5.17). It could also be a reference to Sall., Hist. Fr. 3.77, or, following Susan Weingarten $(2005,178 \mathrm{ff}$.), to Amm., Rer. gest. 35. In the same way Vita Pauli shows a lykos-wolf that guides the protagonist (as in Curt., Hist. Al. 5.4.10). 
critique, the hero's repulsion for ludii, and the information that both Alexander and Hilarion had a favourite, inseparable book: the lliad for the first (Plut., Alex. 8.1-2) and his handwritten Gospel for the other (V. Hilar. 35). The key to explain these similarities is probably the record of Alexander's exclamation in front of Achilles' tomb (Cic., Arch. 24) in V. Hilar. prologue. Here, for excess of exegetical zeal, the saint lists Daniel's various names for the Macedonian leader (Dan 2:32.39; 7:6; 8:5). This might betray Jerome's interest in historical works on Alexander to comment on the prophet; all the more since we know that he was fond of historical writers ${ }^{35}$ (Ammianus Marcellinus ${ }^{36}$ and Aurelius Sextus Victor ${ }^{37}$ above all).

Concerning $V$. Malchi, I will secondarily suggest a few reflections since its narrativity has been already studied ${ }^{38}$, and its dependence on the ancient novel is very explicit. Even if Hagendahl warns us that Jerome's knowledge of Greek literature was indirect and labile, except for exegetical works, ${ }^{39}$ I propose that he somehow read Heliodorus' Aethiopica (maybe for the surmised Christian conversion of its author). Many are the similarities with this work: the opening on a seascape (which signify not life as in Letters, but the narration itself); ${ }^{40}$ the occurrence of linguistic puns and different levels of narration; the tragic allure; the presence of shepherds, barbarians, caves to hide in; and above all the behaviour of Chariclea, a clever woman who elaborates a safety plan and a fake marriage, remaining chaste (Heliod., Aeth., 1.22) precisely as the unnamed heroine in V. Malchi, ${ }^{41}$ and that of Cnemone's father (1.10-11) which resembles that of the abbot in V. Malchi.

At the end of this quick survey on the narration in these works, we can see that Lives and Letters share the aim to narrate (and construct) an ascetic model, its context, and its champions, using classical techniques and sources to found a Christian literature. Unusual scenarios versus real life, exemplar biographies versus choices and episodes (kairos), heroes versus heroines, structured presentation versus spots, saints versus the sinful Jerome are only different aspects of a

35 In fact the biographies of De viris illustribus are historical works inspired by Svetonius and Eusebius of Caesarea, moreover in the prologue of $V$. Malchi he states that he would like to write a major historical work.

36 From Marcellinus, Jerome derives much information about the desert in V. Malchi, while Pliny the Elder and Valerius Maximus are at the base of the knowledge of the fantastic beasts of $V$. Pauli.

37 It is his book that Jerome requests to borrow from Paulus of Concordia in Ep. 10.

38 For the quotation from Apuleius, Longus and Achilles Tatius, see Bauer (1961) and Fuhrmann (1976, 50; 57; 64; 85). For Achilles Tatius' Leucippe and Clitophon, see Šubrt $(2014,207)$. In general, see Gray (2017) and Huber-Rebenich $(1999,199)$, that talks about an "eclectic reception of a variety of models" (Petronius, Apuleius, Lucian, Xenophon of Ephesus). For the relationship with Aeneid and the characters of Dido and Aeneas, see again Grandi $(2015,215)$, Weingarten $(2005,171-174)$ and De Vogüé (19912008, II 91).

39 Hagendahl $(1958,93)$ cites Courcelle, Pierre. 1948. Les lettres grecques en occident: De Macrobe à Cassiodore. Paris: Boccard, and Lübeck, E. F. C. 1872. Hieronymus quos noverit scriptores et ex quibus hauserit. Leipzig: Teubner.

40 Even if the most direct reference is Ambr., Off. 1.10.32-3, as revealed by Harvey $(2005,287)$. The seascape is real in Aeliodorus, metaphorical in Jerome.

41 An interesting challenge is that of Haskins (2018), who presents all the classical and biblical possible identifications of the woman. 
single literary, paraenetic operation intended to convince the public to the monastic cause. The collateral effect is that Jerome is introduced as a remarkable storyteller and a hero: for his addressees and us, he is a friend whose incredible stories and challenges across exotic and queer lands are attractive to listen to. As he says in V. Hilar.: good enterprises need good storytellers, good as Homer, Ulysses, and Jerome...

\section{Abbreviations}

Ambr., Off. - Ambrosius Mediolanensis, De officiis ministrorum.

Amm., Rer. gest. - Ammianus Marcellinus Antiochenus, Rerum gestarum.

Cic., Arch. - Cicero, Pro Aulo Licinio Archia poeta oratio.

CSEL - Corpus Scriptorum Ecclesiasticorum Latinorum.

Curt., Hist. Al. - Curtius Rufus, Historiae Alexandri magni.

Ep. - Epistulae [Hilberg 1910-1918].

Heliod., Aeth. - Heliodorus, Aethiopica.

Hor., Carm. - Horatius, Carmina.

Sall., Hist. - Sallustius, Historiae.

SC - Sources Chrétiennes.

V. Hilar. - Vita Hilarionis [Morales 2007].

V. Malchi - Vita Malchi [Gray 2015].

V. Pauli - Vita Pauli [Morales 2007].

Verg., Aen. - Vergilius, Aeneis.

\section{References}

\section{Primary sources}

Gray, Christa, ed. 2015. Jerome: Vita Malchi. Introduction, text, translation, and commentary. Oxford: Oxford University Press.

Hilberg, Isidorus, ed. 1910-1918. Sancti Eusebii Hieronymi epistulae. CSEL 54-56. Vienna; Leipzig: F. Templsky.

Morales, Edgardo M., ed. 2007. Jérôme: Trois vies de moines (Paul, Malchus, Hilarion). SC 508. Paris: Cerf.

Rosellini, Michaela, ed. 2004. Iuli Valeri Res Gestae Alexandri Macedonis translatae ex Aesopo Graeco. München; Leipzig: Saur.

\section{Secondary sources}

Antin, Paul. 1951. Essai sur Saint Jérôme. Paris: Letouzey et Ané.

Bauer, Johannes Baptist. 1961. Novellistisches bei Hieronymus Vita Pauli 3. Wiener Studien 84:130-137.
Brown, Peter. 1995. Authority and the Sacred: Aspects of the Christianisation of the Roman World. Cambridge, MA: Cambridge University Press.

Bruner, Jerome. 1991. The narrative construction of reality. Critical inquiry 18, no. 1:1-21.

Cain, Andrew. 2009. The letters of Jerome: Ascetism, biblical exegesis and the construction of Christian authority in Late Antiquity. Oxford: Oxford University Press.

- - . 2013. Jerome's Epitaph on Paula: A commentary on the Epitaphium Sanctae Paulae. New York: Oxford University Press.

Cameron, Alan. 2000. Form and meaning: The Vita Constantini and the Vita Antonii. In: Thomas Hägg and Philip Rousseau, eds. Greek biography and panegyric in Late antiquity, 72-88. Berkeley California: University of California Press.

Canellis, Aline. 2002. La lettre selon Saint Jérôme: L'épistolarité de la correspondance hieronymienne. In: Léon Nadjo and Elisabeth Gavoille, eds. 
Epistulae antiquae 2: Actes du lle colloque international „Le genre épistolaire antique et ses prolongements européens", 311-332. Paris: Cerf.

Capponi, Filippo. 1989. Aspetti realistici e simbolici dell'Epistolario di Gerolamo. In: Aldo Ceresa-Gastaldo, ed. Gerolamo e la biografia letteraria, 81-103. Genova: Facoltà di Lettere dell'Università.

Cavallera, Ferdinand. 1922. Saint Jérôme: Sa vie et son œuvre. 2 vols. Paris: E. Champion.

Clausi, Benedetto. 2013. O rerum quanta mutatio! Città e deserto nell'ideologia ascetica e nella scrittura epistolare di Gerolamo. In: Marcello Intrieri and Paolo Siniscalco, eds. La città: Frammenti di storia dall'antichità all'età contemporanea, 123-163. Roma: Aracne.

Colonna, Aristide, ed. 1990. Eliodoro: Le Etiopiche. Milano: TEA.

Consolino, Franca Ela. 1986. Modelli di comportamento e modi di santificazione per l'aristocrazia femminile d'occidente. In: Andrea Giardina, ed. Società romana e impero tardoantico. Vol. 1, Istituzioni, ceti, economie, 273-299. Roma; Bari: Laterza.

Coon, Lynda L. 1997. Sacred Functions: Holy women and hagiography in Late antiquity. Philadelphia: University of Pennsylvania Press.

Courcelle, Pierre. 1948. Les lettres grecques en occident: De Macrobe à Cassiodore. Paris: Boccard.

Cugusi, Paolo. 1983. Evoluzione e forme dell'epistolografia latina nella tarda repubblica e nei primi due secoli dell'impero: Con cenni sull'epistolografia pre-ciceroniana. Roma: Herder.

- - - 1989. L'epistolografia: Modelli e tipologie di comunicazione. In: Guglielmo Cavallo Paolo Fedeli and Andrea Giardina, eds. Lo spazio letterario di Roma antica. Vol. 2, 379-419. Roma: Salerno editrice.

De Jong, Irene J.F. 2014. Narratology and classics: A practical guide. Oxford: Oxford University Press.

De Vogüé, Adalbert. 1991-2008. Histoire littéraire du mouvement monastique dans l'Antiquité: Le monachisme latin. 12 vols. Paris: Cerf.

Fowler, Alastair. 1982. Kinds of literature: An introduction to the theory of genres and modes. Cambridge, MA: Harvard University Press.

Fuhrmann, Manfred. 1976. Die Mönchsgeschichten des Hieronymus: Formexperimente in erzählender Literatur. In: Manfred Fuhrmann, ed. Christianisme et formes littéraires de l'antiquité tardive en Occident, 41-99. Genève: Fondation Hardt.

Gamberale, Leopoldo. 2013. San Gerolamo intellettuale e filologo. Roma: Edizioni di Storia e letteratura.
Gibson, Roy. 2012. On the nature of ancient letter collections. Journal of Roman studies 102:56-78.

Grandi, Giorgia. 2010. II problema del genere letterario delle Vite geronimiane: storia di una scelta ardita e vincente. Adamantius 16:130140.

- - -. 2014a. Amore del sacro e del profano: i diversi volti della pieta in Gerolamo da Stridone. Archivio italiano di storia della pietà 27:177-203.

- - - 2014b. Gerolamo narratore ed epistolografo: per un'indagine dalle Vite alle Lettere. PhD dissertation. Scuola internazionale di Alti Studi "Scienze della cultura", Fondazione San Carlo di Modena.

- - - 2017. Loci amoeni, creature fantastiche e paesaggi incontaminati: Le grotte nelle biografie geronimiane tra realtà e stereotipo. In: Arduino Maiuri, ed. Antrum: Riti e simbologie delle grotte nel Mediterraneo antico, 326-354. Suppl. 82 della Rivista di studi e materiali di storia delle religioni. Brescia: Morcelliana.

- - - 2021. Bethlehem contra Romam? II tema dell'angulus declinato nelle Epistole geronimiane. In: Ingo Schaaf, ed. Hieronymus Romanus: Studies on Jerome and Rome on the Occasion of the $1600^{\text {th }}$ Anniversary of his Death, [forthcoming]. Instrumenta Patristica et Mediaevalia, 87. Turnhout: Brepols.

Gray, Christa. 2017. Holy and pleasing to God: a narratological approach to hagiography in Jerome's Lives of Malchus and Paul. Ancient narrative 14:103-128.

Grützmacher, Georg. 1969. Hieronymus: Eine biographische Studie. 3 vols. Aalen: Scientia Verlag.

Hagendahl, Harald. 1958. Latin Fathers and the Classics: A Study on the Apologists, Jerome and others Christian Writers. Göteborg: Göteborgs Universitets Arsskrifft.

Harvey, Paul B. Jr. 2005. Jerome dedicates his Vita Hilarionis. Vigiliae Christianae 59:286-297. https://doi.org/10.1163/1570072054640531

Haskins, Susan L. 2018. Naming the nameless woman of Jerome's Vita Malchi. HTS Teologiese studies 74, no. 3:1-7. https://doi. org/10.4102/hts.v74i3.5006

Huber-Rebenich, Gerlinde. 1999. Hagiographic fiction as entertainment. In: Heinz Hofmann, ed. Latin fiction: The Latin novel in context, 187-212. London; New York: Routledge.

Kech, Herbert. 1977. Hagiographie als Christliche Unterhaltungsliteratur: Studien zum Phänomen des Erbaulichen anhand der Mönchviten des HI. Hieronymus. Göppingen: Kümmerle Verlag. 
Kelly, John Norman Davidson. 1975. Jerome: his life, writings and controversies. London: Duckworth.

Leclerc, Pierre. 1988. Antoine et Paul: Métamorphoses d'un héros. In: Yves-Marie Duval, ed. Jérôme entre l'Occident et l'Orient, 257-265. Paris: Études augustiniennes.

Lübeck, Emil Friedrich Carl. 1872. Hieronymus quos noverit scriptores et ex quibus hauserit. Leipzig: Teubner.

Lugaresi, Leonardo. 2008. II teatro di Dio: II problema degli spettacoli nel cristianesimo antico (II-IV secolo). Brescia: Morcelliana.

Malherbe, Abraham J. 1977. Ancient epistolary theorists. Ohio journal of religious studies 5:3-77.

McHale, Brian. 2001. Weak narrativity: the case of avant-garde narrative poetry. Narrative 9, no. 2:161-167.

Monaci Castagno, Adele. 2010. L'agiografia cristiana antica: Testi, contesti, pubblico. Brescia: Morcelliana.

Nazzaro, Antonio Vincenzo. 1997. Intertestualità biblico-patristica e classica nell'Epistola 22 di Gerolamo. In: Claudio Moreschini and Giovanni Menestrina, eds. Motivi letterari ed esegetici in Gerolamo, 197-221. Brescia: Morcelliana.

Palmer, Alan. 2004. Fictional minds. Licoln; London: University of Nebraska Press.

Parrinello, Rosa Maria. 2010. Misure del monachesimo a Gaza: dal ,fondatore' Ilarione alla scuola monastica di Gaza. Adamantius 16:164177.

Praet, Danny, Annelies Bossu, Steff Coppieters and Maarten Taveirne. 2014. Martyrdom, literary experiment and Church politics in Jerome's Epistula prima, to Innocentius, on the septies percussa. Vigiliae Christianae 68:384408. https://doi.org/10.1163/1570072012341196

Rousseau, Philip. 1978. Ascetics, authority and the church in the age of Jerome and Cassian. Oxford: Oxford University Press.

Rubenson, Samuel. 2006. Antony and Pythagoras: a reappraisal of the appropriation of classical biography in Athanasius' Vita Antonii. In: David Brakke, Anders-Christian Jacobsen and Jorg Ulrich, eds. Beyond Reception: Mutual influences between antique religion, Judaism and early Christianity, 191-208. Frankfurt am Mein: Peter Lang.

Stoico, Giuseppe. 1972. L'Epistolario di san Girolamo: Studio critico-letterario di stilistica latina. Napoli: Giannini.

Šubrt, Jiří. 2014. Hagiographic romance: Novelistic strategy in Jerome's Lives of hermits. In: Marí- lia P. Futre Pinheiro, Gareth Schmeling and Edmund P. Cueva, eds. The ancient novel and the frontiers of genre, 205-214. Ancient Narrative 18 (Supplementum). Groningen: Barkhuis.

van Uytfanghe, Marc. 2001. L'hagiographie antique tardive: une littérature populaire? Antiquité tardive 9:201-218. https://doi. org/10.1163/15700720-12341196

Vessey, Mark. 1993. Jerome's Origen: the making of a Christian literary Persona. Studia Patristica 28:135-145.

Weingarten, Susan. 2005. The Saint's Saints: Hagiography and Geography in Jerome. LeidenBoston: Brill. 